to that of the non pregnant gilts (net gain of group $4: 33.7 \mathrm{~kg}$ ), without improving the reproductive performances at farrowing (number of piglets : 7.5, mean weight of the piglets : $1.24 \mathrm{~kg}$ ) The nitrogen retention recorded at the end of gestation was higher in group $4: \tau 6.2 \mathrm{~g} \mathrm{~N} /$ day versus 8.9, 9.6 and 9.4 , respectively, in groups $I, 2$ and 3 .

The unfavourable effect of lysine deficiency during gestation had also a repercussion on the performances of the piglets at weaning (number and mean weight $(\mathrm{kg}):$ group $2: 7.5,5.73$; group $3: 7.5,7.25 ;$ group $4: 7.3,8.10$.

Finally, the study of the variations in the blood concentrations of free amino acids shows that there seems to be an evolution in the requirement during the course of gestation. The accumulation of free lysine in the blood can be detected already from the intermediate level, at 60 days of gestation, but can only the determined at the level of $0.62 \mathrm{p}$. Ioo after 90 days of gestation.

The results indicate that the lysine requirement in the pregnant gilt exceeds $0.42 \mathrm{p}$. Ioo of the diet.

\title{
INFLUENCE DE LA RACE ET DU RÉGIME ALIMENTAIRE SUR LA PRÉCOCITÉ SEXUELLE DE LA THUIE
}

\author{
M. ÉTIENNE et C. LEGAULT* \\ Station de Recherches sur l'Élevage des Porcs, \\ * Station de Génétique quantitative et appliquée, \\ Centre national de Recherches zootechniques, I. N. R. A., \\ 78350 Jouy en Josas
}

\section{RÉSUMÉ}

Une expérience portant sur 162 jeunes truies a été réalisée afin d'étudier l'influence de la race et de l'alimentation sur différentes mensurations du tractus génital prélevé à l'abattage des animaux à $95 \mathrm{~kg}$ de poids vif. Les porcs femelles de type "culard " (Piétrain et Landrace Belge) étaient comparés à des témoins Landrace Français. Les animaux recevaient, à volonté, un aliment apportant 3000 kcal ou 3300 kcal d'énergie digestible/kg, et 48 ou 60 g de protéines/ 1 ooo kcal d'énergie digestible. Après dissection du tractus génital, on mesurait et pesait les deux cornes utérines et le vagin. Les ovaires étaient pesés et répartis entre 4 classes de maturité suivant le nombre et la taille des follicules, et la présence de corps jaunes.

D'après la maturité de leurs ovaires, il apparaît qu'au poids vif de $95 \mathrm{~kg}$, les femelles de la race Piétrain sont sexuellement plus précoces que les femelles Landrace français, elles mêmes l'étant plus que les Landrace Belge. Bien que les différences d'âge entre les animaux expliquent partiellement les écarts, le même ordre entre les races se retrouve pour les animaux qui sont d'âge comparable.

L'alimentation n'influence pas de façon significative la maturité des ovaires. Toutefois, dans la race de Piétrain, les aliments à teneur élevée en énergie digestible tendent à retarder la puberté, et il est vraisemblable qu'une différence plus grande de consommation en énergie aurait accentué ces tendances.

Le poids et la longueur de l'utérus augmentent avec la maturité croissante des ovaires, l'effet le plus net étant observé au moment de la puberté. Par contre, le poids et la longueur du vagin ne sont pas modifiés. 


\title{
SUMMARY
}

\section{EFFECT OF BREED AND FEEDING ON SEXUAL PRECOCITY IN THE SOW}

An experiment on 162 young sows was made in order to study the influence of breed and feeding on various measurements of the genital tract taken out after slaughter of the animals at $95 \mathrm{~kg}$ live weight. The female pigs of the "double muscle " type (Belgian Landrace and Pietrain) were compared with controls of the French Landrace. The animals received ad libitum a diet providing $3000 \mathrm{kcal}$ or $3300 \mathrm{kcal}$ of digestible energy $/ \mathrm{kg}$ and 48 or $60 \mathrm{~g}$ of protein $/ \mathrm{I}$ ooo kcal of digest energy. After dissection of the genital tract, the two uterine horns and the vagina were measured and weighed. The ovaries were weighed and divided into 4 classes of maturity according to the number and size of the follicles as well as to the presence of Corpora lutea.

According to the maturity of their ovaries, it appeared that at a live weight of $95 \mathrm{~kg}$, the females of the Pietrain breed were sexually more precocious than the French Landrace females, which showed earlier puberty than the Belgian Landrace. Although the age differences between the animals partially explain these results, the same order between breeds was noted in animals of comparable ages.

The feeding did not significantly affect the maturity of the ovaries. However, in the Pietrain breed, the feeds with a high content of digestible energy tended to delay puberty. It may be that a larger difference in the energy would have emphasized these tendences.

The weight and length of the uterus increased with progressing maturity of the ovaries and this was all the more pronounced at the time of puberty. On the other hand, the weight and length of the vagina did not change.

\section{FACTEURS DE VAIRATION DE LA PRODUCTION ET DE LA QUALITE DE LA SEMENCE DU VERRAT : EFFETS SAISONNIERS, HÉRITABILITE, CORRELATIONS ENTRE VARIABLES}

\author{
F. DU MESNIL DU BUISSON, B. MILLANVOYE, \\ F. BARITEAU et C. LEGAULT* \\ Station de Physiologie de la Reproduction, \\ Centre de Recherches de Tours, I. N. R. A., \\ B.P. 1, Nouzilly, 37380 Monnaie \\ * Station de Génétique quantitative et appliquée, \\ Centre national de Recherches zootechniques, I. N.R. A., \\ 78350 Jouy en Josas
}

\section{RÉSUMÉ}

L'étude a été menée sur 60 verrats Large White obtenus en 6 générations par sélection intra-famille dans io familles (5o couples père-fils). Ces verrats ont été collectés en moyenne une fois par semaine pendant I 5 mois, à partir de leur $7^{\mathrm{e}}$ mois d'âge. Le sperme a été utilisé pour l'insémination artificielle. 